Doctor of Philological Sciences, Professor, the head of the Department of Methodology of Preschool and Elementary School Education Volodymyr Vynnychenko Centralukrainian State Pedagogical University ORCID: http://orcid.org/ 0000-0001-5078-8316 e-mail: alexandr.iliadi@gmail.com HROMKO Tetiana Vasylivna Candidate of Philological Sciences, Associate Professor, Department of Ukraine Language, Volodymyr Vynnychenko Centralukrainian State Pedagogical University ORCID: http://orcid.org/ 0000-0002-4661-4302 e-mail: tvhromko@i.ua

\title{
TESTING AS ONE OF THE FORMS OF CONTROL OF THE IMPLEMENTATION OF LINGUISTIC MATERIAL BY STUDENTS OF THE HUMANITIES (course «Ukrainian for Professional Purpose»)
}

Formulation and justification of the problem topicality. The problem of the quality of professional training of a new generation specialist is one of the key ones for the modern higher education institution. The new requirements for the conception, methodology of education, organizational and methodological support of students provide that, in addition to special humanities knowledge, the higher education institution must form the proper linguistic and communicative competence of the future specialists, that is, to teach them to communicate consciously and competently. These requirements, in our opinion, determine language strategy of each speaker. Therefore, in the educational process it is absolutely important to use methods appropriate to the needs of modern education and aimed at increasing the level of teaching and control of the mastering of linguistic material in educational institutions.

Analysis of previous studies and publications. Linguistic and educational direction of pedagogical testing began to develop in the XX century. Actually, the theoretical basis of the new method is largely attributed to the American psychologist Edward Lee Thorndike in. His book «An Introduction to the Theory of Mental and Social Measurements» [13] was the first to raise problems in pedagogical testing and to contribute to creating of a methodological framework for constructing didactic tests. E. Thorndike's work proved to be timely, since it was the period (early XX century) of the history of science of the linguo-didactic direction of pedagogical testing - language testing. Robert Lado's theory and practice of foreign language testing has been most widely highlighted [12]

Testing as one of the effective forms of control of the linguistic material mastering plays a leading role in foreign and domestic methodical technique. His practical abilities in the process of language learning are devoted in works by K. Ingenkamp, P. Kline,
V. Avanesova, V. Burlachuk, S. Denisenko, G. Kovaleva, T. Kabanova, V. Novikov, M. Galuzinskyy, P. Morozov, L. Babanskiy and others. Such close attention of methodologists is explained with a number of advantages of the test method, for instance, objectivity of assessment, simplicity of test results processing and possibility of standardization of testing procedure.

The purpose of the article. The purpose of the paper is to get the further attention to the possibilities of use of testing (and its types) as a form of control of the linguistic material mastering by students of the humanities.

The maine material of the stuty. The term test is polysemantic, the reason is scientists of different disciplines such as sociology, psychology, pedagogy, psycholinguistics, etc., give this concept not always the same content would be at there is no one clear definition of this category [1, p. 12]. As a means of control, the test is a series of tasks. In general, testing can be represented as a set of sequential steps, starting with the planning and preparation of tests, the actual execution of tests and, finally, the processing and interpretation of test results [8, p. 37]. By L. O. Fedotova and A. A. Rykov, testing is a certain kind of tasks which are to be performed for a limited time. Tests can be implemented both orally and in writing [10, c. 54]. According to S. K. Folomkina, the benefits of testing are concurrent control over a large number of students. Due to the structured organization of tasks in the testing and recording of results by symbols, it is guaranteed that the results will be obtained quickly with the subsequent possibility to analyze them [10, p. 55].

Testing as a form of control the mastering of language material for students of humanities is a complex of pre-prepared and tested tasks, made in accordance with certain requirements. Its main aim is to define qualitative indicator of 
language (linguistic) and speech (communicative) competencies of students. The estimate of the test results is in accordance with prepared criteria.

The value of testing is difficult to overestimate because of its promoting the development of practical skills necessary for the conscious use of linguistic means, as well as the skills of logical thinking and activation of mental activity. Through testing, motivation changes and an individual-personal approach emerges. As a consequence, the concept of estimate the quality of education is beginning to change significantly, encompassing the entire education system as a whole.

In the first stage of learning incoming testing is appropriate, which accompanies the current control through problems in test form and ends on objective testing of educational achievement. In addition to these benefits, tests allow to:

1) establish self-control, which is useful for training and human form of knowledge control;

2) organize rating as an effective means of increasing the educational motivation.

Nowadays, the following types of testing are distinguished in the methodology: educational, control, thematic, diagnostic testing. Comparing to other classical forms of control and reinforcement of students' knowledge (oral or written interview, dictation, translation, creative work, etc.), testing has many advantages like:

- standard of tasks;

- lack of subjectivity from the teacher during the assessment of students' knowledge;

- the ability to capture a large amount of lexical and grammatical material in a short period of time [1, p. 23].

Testing as the main form of control can be used not only to check the mastering of current material, but also at the end of the semester or school year. That is, testing, as a compact form control, helps teachers to identify students have learned specific topics in the discipline and check their level of knowledge and of course at the time of completion of the course. Difficulties in mastering different aspects of a topic the teacher can find out the systematic testing. This will help correct method of teaching material and focus in the most problematic topics. The shortcomings in the quality of tests, unfortunately, is the problem of the teachercompiler, not the technical tool [3, p. 121].

Therefore, testing allows to: reinforce the theoretical material passed; expand active vocabulary and the terminology vocabulary; to develop the skill of the right combination of words and grammatical formulation of phrases, which is especially relevant in the study of paperwork; reduce the number of language errors; to form a holistic view of the functioning of the phrases in the language and others. The systematic application of test control enhances the communicative competence and motivation of the teaching audience.

Specificity mastering linguistic material by humanities students is in the rules of testing. Firstly, the tests should be tailored to the professional specifics of the higher education institution in which the language discipline is studied. Secondly, for qualitative assessment of students' knowledge it is necessary to use different types of test tasks, prepared them and taking into account the level of complexity of the material, for example:

- tests multiple choice (choice and multiple choices);

- alternative choice tests (two choices);

- conformity tests;

- tests to determine the validity or error of assertions;

- comparison tests;

- phrase completion tests;

- tests to remove unnecessary items, etc.

Such tests are based on a topic-specific material to test the level of development of a particular skill. An example of this approach can be signed our testing for unit control disciplines «Ukrainian language for professional orientation», «Modern Ukrainian language with practical work», «Basics of rhetoric», «Rhetoric (for non-philological faculties)», «Communication Technologies» [4], «Technologies of Language Communication» [5].

The so-called «Proportionality»: the higher the content diversity of the test tasks, the lower the reliability of the test result. The point is that a test designed to test the mastering of a particular topic will always be more reliable than a test designed to test the entire section, because it covers a large amount of material. At the same time, it is advisable to find tests that are too complex and too easy to replace with more acceptable ones.

The complexity of the test is determined by the ratio of correct and incorrect answers to the test questions. Bringing on to the tests such tasks that all students do correctly or, conversely, incorrectly, sharply reduces the reliability of the test result as a whole. The greatest practical value are the questions that properly correspond to $45-80 \%$ of students. To determine the degree of learning objectives, we prefer following method: counting percentage of students who completed the task, and the task if performed correctly less than $15 \%$ of students, they are not difficult and if $85 \%$ of students completed the task correctly, they are considered easy [6, pp. 12-13]. 
At the same time, the tests must meet the following methods requirements:

- tests should be short, clear, understandable preferably submitted in the affirmative form;

- ambiguous interpretations are unacceptable when formulating tasks;

- correct answers (if caught in the test) should be evenly distributed;

- the answer to each question should not depend on the answers to other questions;

- the content of the current study material content tests should be relevant;

- the opportunity to guess the correct answer should be minimal (wrong answer should be stated most significantly);

- it is inadmissible to give false information in the test, etc.

The above mentioned test control forms should not completely replace the traditional survey forms, but rather, organically supplement the traditional control, since testing also has certain disadvantages, among which it is advisable to distinguish them (for more details see $[9$, p. 98]):

- lack of creative tasks;

- standardization of knowledge;

- element in randomness in the decision of tests;

- fragmentation of knowledge, etc.

Therefore, testing is not a universal teaching method and form of control, although it helps teachers effectively organize a systematic, multi-stage assessment process and thus provide the conditions for improving the quality of control and mastering of the material as a whole.

It should be pointed out that testing performs a rather wide range of functions, namely: diagnostic, evaluation, training, developmental, motivational, educational, organizational, informational, etc. Among the many functions we distinguish diagnostic, because during the test control it gives an opportunity to assess the quality of students' knowledge, skills and differentiate them by level of preparation. The teacher thus has the opportunity to identify individual difficulties and adjust their educational activities. Equally important is the evaluation function, as it provides quantitative indicators of educational achievement during intermediate or final control. Educational function is implemented in testing to identify gaps in knowledge, fixing them, gaining the ability to work with tests [2]. Testing helps to realize the developmental function if the student and with the needs of self improving and show a desire to improve their results. In general, the predominance of educational and developmental functions of test control occurs under the conditions and relevance of the test tasks to the level of students' readiness. The organizational function is manifested in the change by teacher of the educational process structure with the emphasis on test methods. Educational function of tests is connected with increase of educational motivation, formation of responsibility for learning results. The basic and quality testing are: validity, reliability, differential power, efficiency, objectivity and consistency in the use of educational practice [7, pp.67-68]. It is clear that the testing does not reflect the complete picture of the learning material. For example, it is not possible to test students' ability to express their thoughts clearly, logically, confirm their answer with examples, find knowledge of facts, and so on. It means that testing should always be combined with other traditional forms and methods of verification, then the test results will be most accurate.

It should be pointed out that testing is closely connected with the improvement of monitoring and creating conditions for closer cooperation between students and teachers in the educational process $[11$, p. 180]. After all, the results of the test control make it possible to assess not only the student's ability and degree of diligence, but also the teacher's ability to properly build a program of study, using methods of individualization of learning, available to teach it, etc.

Conclusions and prospects for further researches of directions. Testing students' knowledge is one of the most difficult issues in teaching methods. Pedagogical experience has shown that, in combination with other types of testing, the use of test tasks is a rather effective tool that stimulates students' preparation for each class and increases their motivation for the subject under study. There are a number of benefits to testing. These include:

- the ability to control the work of each student;

- the possibility of systematic test control at all stages of the learning process;

- ability to cover all sections of the curriculum;

- objectivity of test control;

- possibility of conducting traditional and computerized testing;

- uniform requirements for all students;

- high reliability of test control;

- high validity of test control based on the involvement of all didactic units of the training program in the tasks of the tests [2].

Integration processes, which are becoming more and more active at the present stage, indicate that the quality of education is becoming increasingly important. Control, assessment and training are seen as components of a single educational process, and there is an increasing link between control and learning. The systematic conduct of test control during 
employment at higher education institutions gives the opportunity to gradually form competitive specialists in the modern labor market, ready to apply the accumulated luggage of knowledge in further professional life.

\section{СПИСОК ДЖЕРЕЛ}

1. Аванесов В. С. Форма тестовых заданий. Москва, 2006. - 152 с.

2. Бондарь Л.А. Тестування як один із активних методів контролю самостійної роботи в умовах вищого навчального закладу. Сучасні проблеми та шляхи їхнього розв'язання в науці, транспорті, виробництві та освіті. Одеса, 2013 URL: http://www.sworld.com.ua/00106-1 (дата звернення: 01.09.2019).

3. Булах I. Є., Мруга М. Р. Створюємо якісний тест. Київ, 2006. - 160 с.

4. Іліаді О. І., Афанасьєва Л. І., Громко T. В., Жигора І. В. Комунікативні технології [Тестові завдання для модульного контролю 3 дисциплін «Українська мова за професійним спрямуванням», «Сучасна українська мова 3 практикумом», «Основи красномовства», «Риторика» (для нефілологічних факультетів)]. Кіровоград. - 201 с.

5. Іліаді О. І., Афанасьєва Л. І., Громко Т. В., Жигора І. В. Технології мовної комунікації. Кіровоград, 2017. - 122 с.

6. Керівництво Міжнародної тестової комісії з контролю якості підрахунку балів, аналізу результатів та інформування про них = International test commission (2011). Itc guidelines for quality control in scoring, test analysis, and reporting of test scores. URL: http://www.intestcom.org (дата звернення: 01.09.2019).

7. Ковальчук Ю. О. Теорія освітніх вимірювань. Ніжин. 2012. - 200 с.

8. Коккота В. А. Лингводидактическое тестирование. Москва. 1989. - 123 с.

9. Паращенко Л. І., Леонський В. Д., Леонська Г. І. Тестові технології у навчальному закладі. Київ. 2006. - 217 с.

10. Федотова Л. О., Рыкова Е. А. Оценка качества начального профессионального образования. Москва. 2000. - 54 с.

11. Царик Г. М. Переваги та недоліки тестування. Інноваційні технології у викладанні дисциплін мовознавчого блоку в ДВНЗ медичної та фармацевтичної освіти [матеріали семінарунаради завідувачів кафедр української, латинської та іноземних мов у ДВНЗ медичної та фармацевтичної освіти, м. Івано-Франківськ Харків, 20-21 вересня 2012 р.]. Івано-Франківськ. C. $178-181$.

12. Lado R. Language Teaching: A Scientific Approach. New York. 1964. - 239 p.
13. Thorndike Edward L. An Introduction to the Theory of Mental and Social Measurements. New York. 1904. -212 p.

\section{REFERENCES}

1. Avanesov, V. S. (2006). Forma testovykh zadaniy. [Form of test assignments]. Moskva. 152.

2. Bondar, L. A. (2013). Testuvannia yak odyn $i z$ aktyvnykh metodiv kontroliu samostiinoi roboty $v$ umovakh vyshchoho navchalnoho zakladu. Suchasni problemy ta shliakhy yikhnoho rozviazannia $v$ nautsi, transporti, vyrobnytstvi ta osviti. [Testing as one of the active methods of control of independent work in the conditions of higher education. Modern problems and ways of solving them in science, transport, production and education]. Odesa.

3. Bulakh, I. Ye., Mruha, M. R. (2006). Stvoriuiemo yakisnyi test. [Create a quality test]. Kyiv.

4. Iliadi, O. I.,

Afanasieva, L. I.,

Hromko, T. V., Zhyhora, I. V. (2016). Komunikatyvni tekhnolohii. [Communication technologies]. Kirovohrad.

5. Iliadi, O. I.,

Afanasieva, L. I., Hromko, T. V., Zhyhora, I. V. (2017). Tekhnolohii movnoi komunikatsii. [Language Communication Technologies]. Kirovohrad.

6. Kerivnytstvo Mizhnarodnoi testovoi komisii $z$ kontroliu yakosti pidrakhunku baliv, analizu rezultativ ta informuvannia pro nykh [International test commission. Itc guidelines for quality control in scoring, test analysis, and reporting of test scores] = International test commission (2011). Itc guidelines for quality control in scoring, test analysis, and reporting of test scores. URL: http://www.intestcom.org (data zvernennya: 01.09.2019).

7. Kovalchuk, Yu. O. (2012). Teoriia osvitnikh vymiriuvan. [Theory of educational measurements]. Nizhyn.

8. Kokkota, V. A. (1989). Lingvodidakticheskoe testirovanie. [Lingvodidactic testing]. Moskva.

9. Parashchenko, L. I., Leonskyi, V. D., Leonska, H. I. (2006). Testovi tekhnolohii $u$ navchalnomu zakladi. [Test technologies in an educational institution]. Kyiv.

10. Fedotova, L. O., Rykova, Ye. A. (2000). Otsenka kachestva nachalnogo professionalnogo obrazovaniya. [Quality assessment of initial vocational education]. Moskva.

11. Tsaryk, H. M. (2012). Perevahy ta nedoliky testuvannia. Innovatsiini tekhnolohii $u$ vykladanni dystsyplin movoznavchoho bloku v DVNZ medychnoi ta farmatsevtychnoi osvity. [Perevahy ta nedoliky testuvannia. Innovative technologies in teaching the disciplines of the linguistic block at the Higher Medical and Pharmaceutical Education Center]. Ivano-Frankivsk.

12. Lado, R. (1964). Language Teaching: A Scientific Approach. New York.

13. Thorndike, Edward L. (1904). An 
Introduction to the Theory of Mental and Social Measurements. New York.

\section{ВІДОМОСТІ ПРО АВТОРА}

ІЛІАДІ Олександр Іванович - доктор філологічних наук, професор, завідувач кафедри методик дошкільної та початкової освіти Центральноукраїнського державного педагогічного університету імені Володимира Винниченка.

Наукові інтереси: методика викладання курсу «Українська мова за професійним спрямуванням», лінгводидактика тестів.

ГРОМКО Тетяна Василівна - кандидат кандидат філологічних наук, доцент кафедри української мови Центральноукраїнського державного педагогічного університету імені Володимира Винниченка.

Наукові інтереси: методика викладання курсу «Українська мова за професійним спрямуванням».
INFORMATION ABOUT THE AUTHOR

ILIADI Alexandr Ivanovych - Doctor of Philological Sciences, professor, the head of the Department of Methodology of Preschool and Elementary School Education Volodymyr Vynnychenko Centralukrainian State Pedagogical University.

Circle of scientific interests: methodics of teaching the course «Ukrainian for Professional Purpose», lingvodidactics of texts.

HROMKO Tetiana Vasylivna - Candidate of Philological Sciences, Associate Professor, Department of Ukraine Language, Volodymyr Vynnychenko Centralukrainian State Pedagogical University.

Circle of scientific interests: methodics of teaching the course «Ukrainian for Professional Purpose».

Стаття надійшла до редакиї 12.012.2019 р.

УДК 37.378

DOI:10.36550/2415-7988-2019-1-185-24-29

БІДА Олена Анатоліївна доктор педагогічних наук, професор, завідувач кафедри педагогіки і психології, Закарпатський угорський інституту ім. Ференца Ракоці II ORCID: http://orcid.org/ 0000-0002-0448-0852 e-mail: tetyanna@ukr.net

МОІССЕВ Василь Володимирович асистент кафедри педагогіки Національного університету біоресурсів і природокористування України ORCID: http://orcid.org/ 0000-0002-0746-1171 e-mail: kiew07@ukr.net

ГРЕБА Ілдіко Золтанівна викладач кафедри педагогіки і психології, Закарпатський угорський інституту ім. Ференца Ракоці II ORCID: http://orcid.org/ 0000-0002-0764-0858 e-mail: pedagogia@kmf.uz.ua

\section{СФОРМОВАНІСТЬ ПАТРІОТИЧНИХ ЯКОСТЕЙ ЯК ОСНОВА ВИХОВАННЯ ГРОМАДЯНСЬКОЇ ВІДПОВІДАЛЬНОСТІ У СИСТЕМІ ВИХОВНОЇ РОБОТИ}

\begin{abstract}
Постановка та обгрунтування актуальності проблеми. Розбудова України як незалежної, суверенної держави вимагає виховання громадянина-патріота, здатного жити й працювати в умовах демократії, забезпечувати соборність України, відчувати постійну відповідальність за себе, свій народ, країну, прагнути здійснити реальний внесок у реформаторські процеси. Про це свідчать офіційно-нормативні документи: «Національна доктрина розвитку освіти», Державна національна програма «Освіта» (Україна XXI сторіччя)», «Про громадянство
\end{abstract}

України» тощо.

Зважаючи на загострення воєннополітичної, економічної ситуації в Україні, сьогодні виховання справжніх патріотів, безсумнівно $\epsilon$ одним із найважливіших напрямків системи освіти. У першу чергу це стосується виховання молоді, що і зумовило розробку низки керівних документів державного рівня, таких як «Концепція громадянського виховання особистості в умовах розвитку Української держави», «Концепція патріотичного виховання учнівської молоді», «Концепція національно- 